\title{
ESTETIKA MUSIK PADAGENERASI MILENIAL
}

\author{
Berehme Adyatmo Purba \\ Dosen Institut Agama Kristen Negeri Manado
}

\begin{abstract}
Abstrak
Musik saat ini semakin banyak memiliki variasi-variasi trendbaru. Masa kepopulerannya kerap berganti-ganti dengan tujuan mengikuti selera musik yang berkembang di masyarakat. Hal ini menjadisuatu kerumitan untuk mengidentifikasi aspek baru apa yang dapat dikatakan sebagai estetika (keindahan)baru pada musik saat ini khususnyapada generasi milenial.Penelitian ini secara umum bertujuan untuk mengetahui esensi dan tendensi keindahan yang terdapat dalam sebuah karya musik dieramilenial. Melalui penggunaan teori estetika musik yaitu untuk mempersepsi konsep dan elemen musikal dalam musikyang digunakan disebuah gereja padaera milenial saat ini.Bahwa jika dianalisa ada unsur musik yang diminati, misalnya di gereja-gereja yang memiliki instrumen berteknologi moderndenganpenerapan idiom-idiom bunyi dari electronic musical instrument seperti misalnya idiom dub step, pad voice, melalui komposisi sequenser. Ada juga yang menggunakan unsur musik elektronik seperti Syntesizer, Drum Machine, bergaya Electronic Dance Music. Sama halnya yang temui di Gereja International Full Gospel Fellowship (IFGF) Manado, hasil pengamatan menunjukkan bahwa ada yang menggunakan teknologi musik seperti drum pad dalam kebaktian, hal ini menandakan salah satu elemen yang tergolong baru dari segi teknologi dan timbre musikal. Maka dari itu, musik pada generasi milenial yang juga terdapat di gereja yang dalam hal ini yaitu musik yang berteknologi digital. Bahkan dapat dikatakan estetika musik di gereja juga selalu mengikuti perkembangan estetika musik sekuler dalam dunia musik populer.
\end{abstract}

\section{Kata Kunci :Estetika Musik, Musik Gereja, Generasi Milenial}

\section{LATAR BELAKANG}

Saat ini, kemajuan teknologi telah bergabung dalam kehidupan manusia untuk berbagai kategori usia, termasuk remaja. Mereka disebut sebagai generasi milenium, generasi $\mathrm{Z}$ atau generasi digital, yang berarti generasi yang memiliki ketergantungan pada teknologi. Adapun kegiatan-kegiatan yang paling disukai oleh generasi milenial adalah mendengarkan musik dan sangat tertarik untuk menghadiri konser dan festival musik

Banyaknya variasi-variasi trend musik populer (gaya baru), menjadi suatu kerumitan untuk mengidentifikasi aspek baru apa yang dapat dikatakan musik milenial. Genre musik yang disukai bermacam ragam seperti $R \& B$, Hip-Hop dan Top 40 Pop, serta genre-genre budaya populer seperti K-Pop, J-Pop, Regional Meksiko, Bollywood dan musik Spanyol Kontemporer. Pendengar milenial juga ingin tetap terhubung dengan musik negara asal mereka, terutama pendengar Asia dan Latin. Menurut laporan Vevo dari hasil wawancara dengan 2000 pengguna di tahun 2015 pendengar tidak menikmati satu genre sebesar $25 \%$, 
sementara $>60 \%$ selalu berusaha mencari musik-musik baru ${ }^{1}$.

Jika diamati dari aspek penggayaan dan usia, di Indonesia saat ini terdapat sedikit perbedaan antara juniordan senior milenial dalam menggemari musik pop. Sedangkan gaya musik dangdut cenderung lebih disukai oleh junior milennial.Melalui survei yang dilakukan,musik pop (69,3\%)menjadi pilihan pertama, kemudian musik dangdut (20,4\%) menjadi pilihan kedua dan setelahnya musik jazz $(4,3 \%)$ serta rock (4,2\%). Mayoritas milenialmenggunakan aplikasi HP / smartphone untuk mendengarkan musik. Temuan ini tentunya sangat wajar mengingat smartphone sangat praktis dan mudah dibawa kemana saja, sehingga saat kapanpun bisa mendengarkan musik. Sedangkan aplikasi yang paling sering digunakan untuk mendengarkan musik adalah JOOX dan Spotify. 51.6\% milenial mendengarkan musik melalui aplikasi streaming atau download secara ilegal (IDN, 2019) $)^{2}$.

Uraian di atas menunjukkan bahwa musik adalah salah satu produk yang tidak dapat dipisahkan dari kehidupan generasi

\footnotetext{
${ }^{1}$ Alexander Haryanto, Memahami Selera Musik Milenial, Tirto(19 November 2016)

${ }^{2}$ Research IDN Institute,Indonesia Millennial Report 2019 (IDN Media, 2019)
}

milenial.Banyaknya persentase pendengar yang selalu mencari musik-musik baru atau genre baru merupakanfenomena yang sangat cepat berkembang dalam lingkup musik populer. Indonesia sendiri saat ini kecenderungannya mencari musik-musik baru dengan sangat cepat melalui media streaming maupun download langsung. Tersedianya kategorisasi pilihan jenis musik dengan tampilan yang mudah untuk diperoleh sebagai referensi musik. Kini mendengarkan musik favorit dapat dengan mudah karena adanya playlist sebagai kumpulan musik-musik berisi selera pendengar yang telah lebih dulu dicari.

Akan hal itu generasi milenial memiliki selera musik yang berbeda-beda akan pemilihanjenis musik. Tentu karena berasal dari pengalaman dan pengetahuan akan keindahan musik setiapmasing-masing individu. Adapula berdasarkan latar belakang akan pengenalan musik yang berasal dari kultur seni budaya yang berbeda. Pemahaman tentang musik pada generasi milenial kebanyakan masih seputar musik populer yang bertemakan kegembiraan, semangat dan positif.Hal itu dilakukan sebagai upaya keluar dari kenyataan hidup yang sulit, sekaligus menunjukkan kurang berminatnya generasi milenial terhadap musik-musik yang berbicara tentang kematian, kemiskinan dan kelaparan ${ }^{3}$.

Jika dikaitkan dengan musik-musik bertemakan rohani atau spriritual dengan gaya

\section{${ }^{3}$ Ibid}


musik populer tersebut, maka akan ditemukan juga beberapa kebaruan aspek yang perlu untuk diketahui denganberbagai pertimbanganpertimbangan seperti misalnya tempat dan cara penyajian yang berbeda dari musik kebanyakan berbau syair-syair sekuler tanpa adanya tujuan agama tertentu, kemudian seperti dokrin akan mazhab terhadap cara peribadatan di dedominasi gereja.

Di lingkungan gereja kharismatik, musik punya peran khusus dalam keberlangsungan ibadah umat Kristiani. Perkembangan musik digereja saat ini tidak lepas dari kemajuan musik populer dari luar gereja. Seperti misalnya unsur-unsur intrinsik musik yang diproduksi untuk kalangan umat gereja, sama seperti yang diproduksi untuk masyarakat umum diluar gereja, namun yang membedakan adalah aspek keindahannya. Maka dari itu, penelitian ini diarahkan pada penelusuran akan keindahan musik yang bertemakan gereja (kekristenan).Teori-teori seputar estetika musik merupakan faktor utama dalam mengkaji aspek keindahan musik dari generasi milenial.

Tujuan penelitian ini untuk mengulas secara substansi estetika musik generasi milenial (intramusikal) dengan mendeskripsikan unsurunsur intrinsik dan ekstrinsik keindahan dari musik saat ini yang memiliki popularitas di kalangan milenial kristiani. Kemudian menganalisis sebuah lagu pop rohani sebagai objek sampel pembahasan aspek intramusikal. Melalui penelitian ini diharapkan dapat memperoleh pengetahuan atas salah satu karakteristik musik pada generasi milenial.

Metode yang digunakan pada penelitian ini yaitu metode penelitian kualitatif deskriptif dengan pengumpulan data melalui observasi, wawancara, dan kajian literatur. Adapun pendekatan yang digunakan adalah analisis musikologi, sebagai upaya untuk menganalisis elemen musik seperti instrumentasi, timbre, dan bentuk/struktur komposisi.

\section{KERANGKA TEORI}

Estetika kerap dikenal suatu istilah yang selalu diperdebatkan dari zaman ke zaman. Kemunculannya di zaman prasejarah ke zaman klasik hingga kontemporer yang mana masingmasing memiliki hakikat pemahaman akan estetika. Zaman prasejarah, estetika diketahui sebagai persepsi estetis atau cara memandang seni secara terpisah dari aspek-aspek non-seni, sementara zaman kontemporer bertumpu melalui karya seni yang dihadirkanoleh figur tokoh saat itudengan dimensi waktu yang sedang bergulir.

Secara etimologi,estetika berasal dari bahasa Yunani, aesthetikos, artinya “persepsi”.Sebagai kata benda adalah aisthesis yaitu "persepsi indrawi”, seperti penglihatan, pendengaran dan juga melibatkan perasaan ${ }^{4}$.

Alexander Gottlieb Baumgarten (1714-1762) adalah seorang ahli filsafat yang pertama sekali menggunakan estetika. Dengan mengikuti pendapat filsuf G.W Leibniz (1646),

${ }^{4}$ Liang Gie. Garis Besar Estetik (Filsafat Keindahan). Yogyakarta : Supersukses, 1983) 
Baumgarten membedakan antara pengetahuan intelektual dengan pengetahuan inderawi. Pengetahuan intelektual itu disebut juga pengetahuan tegas, sedangkan pengetahuan inderawi dianggap sebagai pengetahuan kabur. Namun jika meneruskan distingsi Yunani antara noesis dan aesthesis, Baumgarten memilih dua jenis pengetahuan cognitio intellective dan cognitio aesthetica. Jenis pengetahuan kedua itulah yang kemudian dikenal dalam bentuk singkatnya: aesthetica ${ }^{5}$.

Istilah ini merupakan cabang ilmu filsafat yang membahas tentang keseniandalam hal ini bermanfaat untuk mengupasdomain keindahan sebuah karya seni. Keindahan merupakan sesuatu yang dapat memberikan sebuah kesenangan atau kebahagiaan.Terdapat suatu kebaikan dari setiap keindahan yang diperoleh dari logika manusia lewat penggunaan indera. Estetik pada umumnya berkaitan dengan pembahasan antara objek-objek seni dengan ekspresi pelaku seni yang koheren.

Liang Gie, 1983 menyebut estetika sebagai salah satu cabang filsafat seni sejak zaman Yunani Kuno sampai sekitar pertengahan abad ke-18 disebut dengan berbagai nama yaitu, filsafat keindahan (philosophy of beaty), filsafat cita rasa (philosophy of taste), filsafat seni (philosophy of art), filsafat kritik (philosophy of criticism). Terkadang juga diganti dengan 'theory', sehingga dengan demikian dikenal pula sebutan-sebutan seperti : teori keindahan, teori citarasa, teori seni indah dan teori lima seni

${ }^{5}$ Ibid seperti lukis, pahat, arsitektur, sajak, musik. ${ }^{6}$

Sama halnya dengan estetika musik yaitu upaya dalam mengkaji tentang hakikat keindahan musik, mempersepsi tentang ukuran keindahan musik serta filosofi keindahan musik. Secara umum estetika musik juga dapat dianggap sebagai filsafat keindahan musik. Walaupun sebenarnya estetika musik tidak terpatok pada keindahannya saja,namun ada juga sublimasi dari setiap karya lewat ekspresi saat mendengarkan sebuah musik.

Estetika dalam tatanan seni musik menurut Suka Hardjana (2018)dapat dianggap sebagai teori atau pengetahuan yang mencoba untuk menerangkan bagian keindahan objeknya, atau diartikan sebagai suatu pengetahuan atau penelaahan tentang aspek keindahan musik.Namun agar tidak membatasi pengukuran substansi musik bahwa sesuatu musikdapat dipersepsi sebagai suatu yang tidak indah.Estetika musik dalam hubungannya dengan kreativitas manusia yang tidak melulu harus indah, karena yang tidak indah juga merupakan totalitas musik serta pengetahuan atau usaha penelaahan tentang hubungan antara cita rasa dan kesadaran intelektual manusia dengan musik $^{7}$

Penelitian tentang psikologi musik yang membahas sebuah studi tentang musik di industri restoran yang dikunjungi oleh kalangan milenial. Penyelidikan yang dilakukan

${ }^{6}$ Ibid
${ }^{7}$ Suka Hardjana, Estetika $\quad$ Musik
(Yogyakarta: Art Music Today 2018) 
Kusumawardhana, Saptaputra \& Ramdan (2019) tentang genre musik di ruang restoran terhadap pelanggan milenial, bahwa musik-musik popular tentang perjodohan dan volume musik akan meningkatkan masa tinggal mereka yang lebih lama serta mengurangi kebosanan, yang mana kadang kala layanan yang tidak menyenangkan atau ketidakseimbangan desain / arsitektur restoran ada ditemui. Namun sebenarnya sebagian besar pelanggan restoran yang datang termotivasi untuk memuaskan rasa lapar mereka $^{8}$.

Tokoh-tokoh ahli astromoni dan matematikawan banyak memengaruhi aspek kehidupan manusia, termasuk musik pada abad 18. Istilah Aesthetic Copernican Revolution, mengubah pemahaman umum filosofis musik sebagai seni. Kajian filosofis dari Lawren (2019) membahas tentang enam kriteria musik (media musik, konsep karya musik, fungsi musik, harmoni, struktur dinamika dan tematik musik) yang mengalami reorientasi. Pada akhirnya pemahaman ini mengarah pada reorientasi estetika, mempengaruhi konsepsi kita tentang sifat seni, dan menimpa metafisika dengan adanya redefinisi secara implisit bahwa subjek berperan dalam pengalaman estetika ${ }^{9}$.

Dari berbagai literatur diatas menunjukkan bahwa estetika dapat digabungkan

\footnotetext{
${ }^{8}$ Kusumawardhana dkk, Towards millennial's music genre: psychology of music in a restaurant(Research Gate, 2019)

${ }^{9}$ Jürgen Lawrenz, Music and the Aesthetic Copernican Revolution of the Eighteenth Century (The European Legacy, 2019)
}

dengan domain bidang ilmu selain musik. Seniseni selain musik yang dijadikan sebagai subjek bahkan diluar seni menjadi menarik ketika pembahasan estetika bertaliandengan banyak ilmu pengetahuan. Maka penelitian estetika musik pada generasi milenial ini memiliki ruang pemikiran dan penyelidikan suatu musik di era modern saat ini terkhusus pada generasi milenial.

Untuk lebih memfokuskan pembahasan fenomena yang ada diperlukan ada batasan teori sebagai upaya untuk menjawab pertayaan penelitian. Teori-teori tersebut di atas dapat menunjukkan bahwa gejala yang ada mampu dijelaskan secara konkret dengan mengungkap unsur-unsur keindahan atau ketidakindahan musik di masa milenial. Maka estetika musik selain membahas persoalan asalusul sejarah estetika musik berbagai zaman, akan tetapi juga tentang musik berdasarkan intrinsiknya seperti timbre alat musik dan tematema struktur musik.

\section{HASIL DAN PEMBAHASAN}

\section{Perkembangan Estetika Musik}

Pada bagian ini penjelasan tentang perkembangan sejarah estetika musik secara garis besar yang periodisasinya akan dijabarkanmulai dari masa barok hingga modern.Karena runtutan pengetahuan tentang estetika perlu dijelaskan agar dapat diketahui asal usul dan ragam persepsi tentang musik.

Sejarah musik di Barat pada awalnya memiliki latar belakang yang melewati masa- 
masa kelam. Lalu muncullah masa pencerahan sebagai logika untuk memulai sejarah dari abad Pertengahan, Renaisans, Barok hingga ke musik klasik berkembang sebagai bentuk seni yang terstruktur. Komposisi-komposisi musik berkembang melalui struktur dan dimensi nada dengan estetika masing-masing zaman.

Estetika Musik masa Baroksejatinya musik yang dihubungkan dengan kebesaran Tuhan, musik tidak untuk kepentingan diri sendiri. Memiliki ciri sendiri yang harus religious, aspek intrinsik dari musiknya yang kerap menggunakan figur bass continuo. Selama periode Barok, demi musik yang indah ide musik muncul dengan berbagai macam bentuk seperti halnya kelahiran musik instrumental, hingga mencapai puncaknya pada opera. Kemunculan opera menjadi suatu trend baru yang mengkombinasi antara tarian, nyanyian, drama, dan alat-alat musik mahal, estetika atau keindahan seperti ini belum pernah terbanyangkan sebelumnya. Concerto dan sonata merupakan pertunjukan keahlian yang menonjolkan satu instrumen, yang juga menjadi gaya khas periode Barok $^{10}$.

Berbeda dengan era klasik musik bertujuan agar menghasilkan suatu parameter estetika musik yang ideal serta bersifat impersonal. Musik era klasik bergejolak secara politis, berfokus pada kesatuan struktural, kejelasan, dan keseimbangan.Tidak berfokus

\footnotetext{
${ }^{10}$ Sunarto, Estetika Musik: Autonomis versus Heteronomis dan Konteks Sejarah Musik (Promusika Junal Pengkajian, Penyajian, dan Penciptaan Musik, 2016)
}

pada kata-kata,visual, atau bagian non-musikal akan tetapi pada intrinsik musik. Dalam mendengarkan karya klasik, seseorang dapat mengalami reaksi internal, yang pada gilirannya memicu penyelidikan filosofis ke dalam sifat pendengaran musik. Musik klasik melibatkan indera aural sebagai lawan dari visual, dan estetika musik diinternalisasi melalui pendengaran. Pembuatan komposisi musik klasik mempertimbangkan proporsionalitasdari setiap penggunaan elemen musik yang tidak berlebihan ${ }^{11}$.

Musik romantik yang dipengaruhi paham rasionalisme subjektif, menjadikan khayalan sebagai kenyataan, pikiran individualis atauyang tidak memiliki patokan gaya musik zaman ini.Para ahli filsafat seperti Kant dan Schopenhauer mendiskusikan pengaruh musik dalam hal keindahan, emosi, dan ekspresi kehendak. Selain itu, para filsuf juga memeriksa struktur, poladan pergerakan suara dalam setiap karya musik karena mereka secara estetika berhubungan dengan pendengar. Yang dapat diperhatikan dari estetika musik zaman ini, diketahui dari persona komponis lewat karya yang dibuat cenderung sangat dinamis ${ }^{12}$.

Estetika musik abad modern tidak sekedar bentuk dan isi, namun emansipasi keindahan, sistem tonal menjadi a-tonal, elektronis, keindahan dari media teknologi yang mengandal musik digital. Misalnya musik konrit

\footnotetext{
${ }^{11}$ Ibid

${ }^{12}$ Supriyadi, Nilai Estetis Musik dalam Rentang sejarah Musik Barat (Tonika, 2019)
} 
(concrete), dihasilkan dari bunyi real alat-alat musik yang memiliki pitch atau yang berasal dari benda-benda non-musikal defenite pitch Pierre Scaeffer (1910) dalam karyanya merekam bunyi kereta api uap dan bunyi alat-alat dapur sebagai bunyi musik. Tentu sering terjadi perdebatan jikalau mempersepsi musik concrete menggunakan paham estetika musik klasik dipahami sebagai suatu yang indah. Tendensi dalam hal keindahan tidak memiliki parameter yang mengacu pada salah satu gaya tertentu akan tetapi sudah sangat otonom tanpa pengaruh komposer lain. Kemunculan bentuk musik seperti itu merupakan bagian dari tuntutan orijinalitas yang semestinya untuk memenuhi kaidah-kaidah estetika musik zaman modern. Itu sebabnya dalam hal estetika musik sulit untuk digeneralisasi seperti zaman-zaman sebelum zaman modern ${ }^{13}$.

Sedangkan estetika pada budaya populer, tidak terlepas dari istilah budaya populer yang berarti budaya masyarakat pada umumnya (culture of the people) yang hidup (lived culture) dalam kehidupan masyarakat kebanyakan, berkembang sejalan dengan perkembangan industrilisasi, produksi massa dan media massa, yang berkaitan dengan budaya massa (mass culture) ${ }^{14}$ Tidak jauh dari itu estetika musik pada generasi milenial juga banyak terpengaruh oleh selera musik yang diminati di kalangannya. Misalnya musik yang

\footnotetext{
${ }^{13}$ Ibid

${ }^{14}$ Nafis, dkk, Estetika Musik Zapin Sebagai Budaya Populer di Pekanbaru (Padang Panjang, Bercabik :2014)
}

popular di masyarakat lokasi-lokasi perbelanjaan, angkutan-angkutan umum dijalanan, atau disekolah-sekolah dapat menstimulasi pendengar kalangan milenial. Musik popular dalam konteks lagu-lagu rohani di lingkungan gereja juga dapat menstimulasi jemaat agar dapat menyenangi atau menyanyikan. Baik itu karena aspek intrinsik maupun ekstinsik musik yang didengarkannya.

Praise and Worship (pujian dan penyembahan) adalah nyanyian untuk memuji serta menyembah Tuhan didalam peribadatan aliran gereja kharismatik. Kharismatik yang bertujuan untuk memuji dan menyembah Tuhan dilakukan melalui nyanyian dan penyajian musik. Kecenderungan penggunakan gaya musik di gereja kharismatik yaitu musik pop ${ }^{15}$. Berbeda halnya dengan gaya musik padagereja beraliran lutheran masih tetap menggunakan nilai-nilai estetis dari musik hymn yang erat kaitannya dengan sebuah liturgi konventional. Perbedaan penggunaan musik tersebut ditentukan oleh pemimpin lembaga gereja, dalam hal ini dapat dikatakan sebagai dogma yang dijadikan sebagai media pujian kepada Tuhan dan juga untuk menunjukkan jati diri masing-masing gereja. Jika ditinjau dari sejarah, ada beberapa konteks cara peribadatan Kristiani yang berkembang hingga saat ini yakni kontekstualisasi musik ibadah Kristen di masa kekaisaran Romawi, kontekstualisasi musik ibadah Kristen di masa

\footnotetext{
${ }^{15}$ Wijiyanto, dkk. Musik Gospel Sebagai Ekspresi Spritual Kristen Kharismatik (Journal of Urban Society's Arts, 2014)
} 
reformasi (Jerman, Belanda), kontekstualisasi musik ibadah Kristen di masa Amerika. Perbedaan konteks tersebut didasari oleh ajaran seperti calvinis maupun lutheran. Namun penelitian ini akan mengarah pada satu konteks ibadah di gereja yaitu pada kontekstualisasi dalam idadah gereja kharismatik.

Ada beberapa kalangan dalam sebuah lembaga gereja saat ini salah satunya yaitu generasi milenial. Generasi milenialmerupakan golongan demografi setelah generasi baby boomers, dan generasi X. Batas waktu berada pada sekitar tahun 1980 sampai awal tahun 2000. sedangkan generasi $\mathrm{Z}$ merupakan generasi yang lahir setelah tahun 2000 hingga saat ini. Generasi milenialberbeda dengan dengan generasi sebelumnya karena banyak dipengaruhi oleh munculnya smartphone, meluasnya internet dan munculnya jejaring sosial media. Hal tersebut banyak mempengaruhi pola pikir, nilainilai dan perilaku yang dianut.

Hasil riset yang dirilis oleh Pew Research Center dalam Ali \& Purwandi (2016) secara gamblang menjelaskan keunikan generasi milenial dibanding generasi-generasi sebelumnya. Yang mencolok dari generasi milenial jika dibanding generasi sebelumnya adalah soal penggunaan teknologi dan budaya pop/musik. Kehidupan generasi milenial tidak bisa dilepaskan dari teknologi terutama internet, entertainment/hiburan sudah menjadi kebutuhan pokok bagi generasi ini ${ }^{16}$.

${ }^{16} \mathrm{Ali}$, dkk.The Urban Middle-Class Millennials(Jakarta: Alvara Research Center, 2016)

\section{Unsur Nilai Estetis Musik pada Generasi Milenial}

1. Analisis Elemen Musikal

Analisis musikal dilakukan untuk mengetahui bagian-bagian yang terkandung dalam sebuah karya musik. Bentuk musik diamati dan kategorinya ditentukan berdasarkan unit-unit terkecil hingga terbesar seperti figur, motif, frase hingga periode. Hal ini untuk mengetahui nilai yang terkandung dari sebuah karya musik melalui ilmu analisa musik yang secara umum dibagi menjadi dua teknik yaitu menganalisis bentuk lagu dan bentuk musik instrumental.

Ada empat aspek intramusikal seperti golongan berikut: pitch, durasi, volume (intensitas), dan timbre (warna suara). Pitch berhubungan dengan melodi, harmoni, dan kontrapung. Durasi berhubungan dengan tempo, ritme, meter, dan beat. Volume berhubungan dengan dinamika keras lembutnya. Dan timbre berhubungan dengan warna vokal, warna instrumental, dan sumber produksi suara lainnya (Christ, 1975). Hasil penelitian ini yang perlu diketahui menekankan pada analisis unsur timbre yakni yang berhubungan dengan produksi suara instrumental. Karya musik yang menjadi fokus untuk objek analisis yaitu sebuah lagu yang populer di kalangan milenial kristiani.

Adapun karya musik yang di analisis 
yaitu salah satu karya musik bergaya pop berjudul 'Aman di Tangan-Mu' yang dipopulerkan oleh kelompok musik IFGF Praise. Popularitas lagu tersebut saat ini banyak diminati khususnya kalangan gereja kharismatik. Komposisi lagu 'Aman di Tangan-Mu'dalam format combo bandmenggunakan instrumen gitar, bass, drum akustik, drum pad, synteziser, keyboard dan vokal. Vokal memiliki peranan penting di mana vokalis utama sebagai pemandu nyanyian pokok dan backing vokal sebagai penyanyi pendukung yang memberi harmoni pada lagu. Komposisi lagu ini berbentuk binary form atau bentuk lagu dua bagian yang terdiri dari bagian tema A dan bagian bema B. Lagu ini juga terdapat sisipan bagian transisi, atau dalam istilah musik populer yaitu pre-chorus. Lagu ini dimainkan pada kunci $\mathrm{C}$ mayor dengan tempo allegro (cepat) yaitu 125BPM (Beat Per Minute) pada jenis sukat quadruple atau hitungan empat dan memiliki ambitus nada yang terendah yaitu nada $\mathrm{C} 4$ dan tertinggi nada E5.

Sebelum masuk ke bagian tema A, terdapat bagian introduksi atau bagian music pembuka sebanyak 4 birama yang memainkan progresi akor Am-F-C-G dalam 4 kali repetisi (pengulangan). Yang menarik dalam lagu ini adalah penggunaan komposisi sequenser di awal lagu atau pada bagian introduksi. Bagian ini merupakan melodi awal ciri khas dari pada lagu 'Aman ditangan $\mathrm{Mu}$ ' karena ada pengolahan komposisi sequenser dan instrumensynteziser membawakan melodi yang dijadikan sebagai tematis pada bagian introduksi dengan pengolahan repetisi.

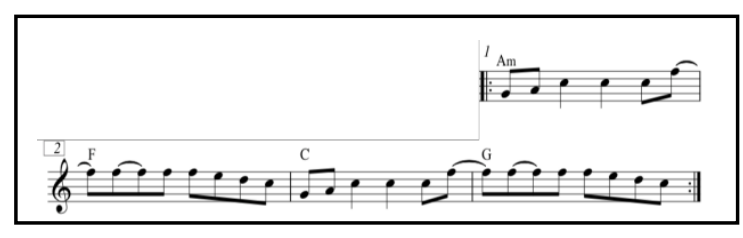

Gambar 1. Potongan Introduksi

Jika diperhatikan, esensi dari karakter musik dari instrumen yang berunsur elektronis tersebut ditemukan beberapa unsur yang berbeda dari band pada umumnya seperti penggunaan instrumen synteziser dan drum pad. Penggunaan drum pad pada lagu ini memiliki kesan lebih kaya akan timbre (warna suara). Menambahkan unsur yang dinamis seperti tone colour bagian low dengan pola ostinato (pola berulang) yang jatuh pada ketukan kuat atau ketukan pertama dan ketiga dalam dalam satu biramadijadikan untuk mewakili kick drum yang berubah menjadi lebih 'deep' dan 'wide' dibanding drum akustik pada umumnya yang lebih flexibel karena kekuatan atau kualitas bunyi tergantung pada tekanan yang dihasilkan antara 'bright' atau 'warm'.

Komposisi synteziser dalam lagu ini menjadi bagian terpenting karena berfungsi sebagai patron / patokan setiap instrumen 
yang membawakan ataupun berfugsi sebagai dasar untuk menyamakan ketukan. Lalu dari aspek timbre, seiring berjalannya lagu dapat meng-cover peleburan timbre antara instrumen akustik dan elektrik. Perpaduan yang dihasilkan dari komposisi elemen musikal lagu ini bertujuan untuk menghasilkan efek bunyi yang dinamis sehingga memiliki nilai estetis yang kaya warna suara.

Tema A pada lagu initerdiri dari 15 birama yang memiliki satu kalimat kemudian diulang dengan motif yang sama. Tidak ada perbedaan kontras dari kedua frase tersebut namun pada bagian awal menjadi pembedanyaadalahnada awal frase. Tema A dimulai dari birama 17, dimulai dengan akor tonika (akor tingkat I), dimainkan dalam progresi C-Am-G-C dan diakhiri dengan kadens otentik dengan progresi V-I. Kemudian dengan tema melodi yang sama terdapat repetisi tema pada birama 24 yaitu sebuah pengulangan yang bermaksud untuk memperkuat tema sebelum melangkah pada bagain tema selanjutnya.

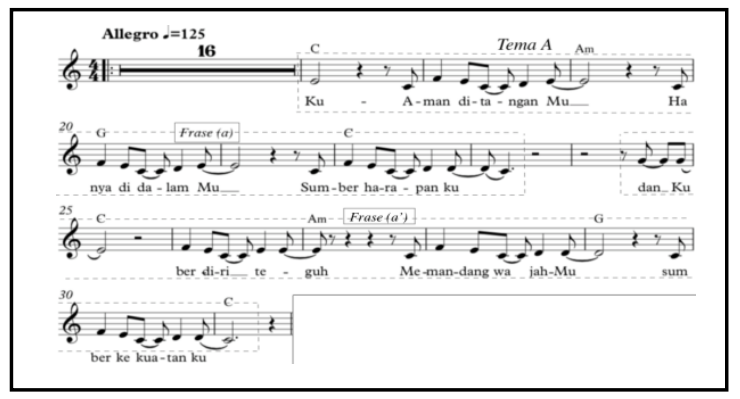

Gambar 2. Potongan notasi Tema A
Setelah Tema A terdapat bagian transisi yaitu dalam birama 32-39. Dirangkai dalam dua frase yang berulang. Frase pertama (frase transisi (a) dimulai dengan ketukan ringan atau hitungan empat. Kemudian frase kedua diulang dengan perbedaan nada akhir frase yang berhenti pada nada do (tingkat akor I).

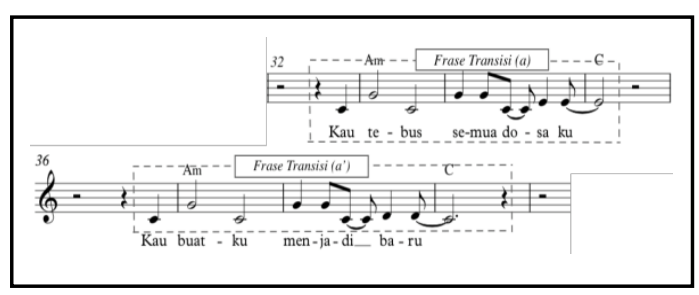

Gambar 3.Potongan notasi bagian transisi

Sedangkan bagian tema B terdapat dalambirama 40-55 dimulai dengan frase yang kontras antara tema A dengan tema B. Tema B terdiri dari 16 birama yang memiliki satu kalimat kemudian diulang dengan motif yang sama. Tema B dimulai oleh frase (b) dalam birama 40 dimulai dengan akor tonika dimainkan dalam progresi C-Am-G-F. Kemudian frase (b') merupakan melodi yang sama dengan repetisi tema dimulai pada birama 48, bagian sebuah pengulangan yang divariasi pada akhir kalimat tema B dengan puncak nada berhenti di nada re pada akor tingkat I. 


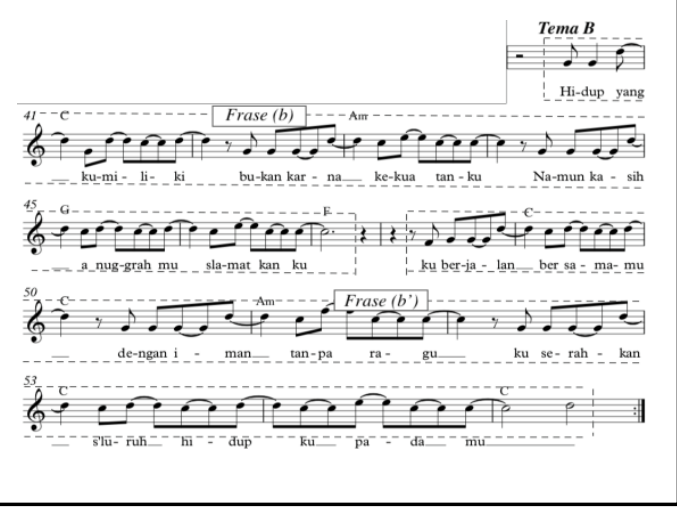

Gambar 4. Potongan notasi bagian Tema B

Oleh sebab itu, berdasarkan analisis di atas dapat disimpulkan bahwa penggunaan sarana media sajian musik yaitu dengan mengandalkan teknologi digital. Kelebihan dari menggunakan instrumen digital adalah tidak memerlukan banyak pemain dan banyak alat musik untuk memainkan rangkaian aransemen. Teknologi musik digital membantu untuk membangun kesan baik ketika praise maupun worship supaya suasananya terkesan lebih meriah, soundscape yang lebih luas, dan menciptakan suasana yang ceria, khusuk dan "mewah". Dengan adanya teknologi musik digital membantu gereja untuk menjangkau generasi muda di gereja dengan cara meningkatkan kualitas musik yang mengikuti perkembangan zaman dengan genre musik yang sesuai dengan genre musik generasi yang menjadi target penjangkauan yaitu anak muda. Kemampuan untuk menyamakan kualitas sound pada lagu asli yang dijadikan rujukan dalam songlist dua bulanan dan kualitas sound pada saat latihan dan live ketika kebaktian berlangsung (Saputra, 2017)

Penggunaan teknologi musik digital difokuskan kepada penggunaan sound dan effect yang dibuat dalam bentuk soundbank dan sequencer yang memungkinkan untuk dimainkan bersamaan dengan alat musik standar band yang digunakan kebanyakan Gereja Kristen Kharismatik. Soundbank dan sequencer digunakan dalam kebaktian di Gereja International Full Gospel yang dibuat dan dioperasikan dengan menggunakan aplikasi mainstage yang dilengkapi dengan virtual instruments dari beberapa pengembang seperti spectrasonic, east west, dan kontakt.

Musik yang dekat dengan generasi ini dapat diindikasi salah satunya yaitu yang mengutamakan teknologi digital seperti drum pad dalam golongan electronic musical instrument. Adapun idiom-idiom gaya musik digital seperti: dub step, pad voice, techno, dan seterusnya merupakan hasil dari pegolahan unsur musik elektronik seperti syntesizer, drum machine, bergayaelectronic dance music (EDM).

2. Persepsi Nilai Estetis Musik Pada Generasi Milenial

Musik dapat dipahami dan mengerti melalui pengalaman yang diturunkan dari generasi ke generasi. Cara-cara berpikir dan melakukan aktifitas musik yang dilakukan 
oleh sebuah kelompok tentang musik menjadi sebuah budaya musik. Karena pengalaman orang Tapanuli berbeda dengan orang Jawa dan orang Bali. Orang Tapanuli senang pada suara-suara melengking, orang Jawa senang bunyi yang tenang, orang Bali senang pada suara-suara gaduh. Tentang baik buruknya suatu bunyi itu ditentukan oleh benak seseorang, terbentuknya ideal atau penghayatan.

Hardjana (2018) menyebutkan tentang sugesti musik mengakibatkan adanya relativitas terhadap apa yang dianggap cocok dan baik menurut ukuran estetika maupun perasan artistik masing-masing orang. Misalnya suara lokomotif mengganggu banyak orang, namun bagi orang lain itu dapat dianggap indah.Sugesti bunyi dibentuk oleh pengalaman, pendidikan, kebiasaan atau khayalan. Misalnya, lewat pengalaman seperti orang Jawa menggemari suara burung perkutut, orang Tapanuli senang pada suara-suara melengking. Dalam pelajaran bernyanyi kita diajarkan cara-cara membentuk suara dengan metode yang benar ${ }^{17}$.

Pemilihan jenis musik juga ditentukan oleh kebiasaan seseorang dalam mendengarkannya. Bagi pengguna musik sangat dipengaruhi oleh keberadaan sebuah karya musik eksis dalam masyarakat.

\footnotetext{
${ }^{17}$ Suka Hardjana, Estetika Musik (Yogyakarta: Art Music Today 2018)
}

Musik banyak digunakan kepentingan politik untuk kampanye, pendidikan sebagai media pembelajaran, kegiatan-kegiatan sosial dan juga untuk kepentingan agama seperti di gereja. Itulah sebabnya penentuan jenis/genre musik yang dianggap indah itu tidak lepas dari kebiasaan sebuah kalangan dalam menggunakannya. Karena dibentuk oleh sugesti, bunyi yang dipandang lebih memiliki nilai estetis secara lahiriah. Saat ini, jenis/genre musik yang banyak digunakan oleh beberapa kalangan termasuk generasi milenial didominasi oleh musik bergaya pop. Musik pop lebih menekankan sisi menghibur, mengumpulkan massa kerena karakter musikal yang mudah untuk dinikmati dan dipahami.

Seperti misalnya praise and worship (pujian dan penyembahan) adalah aktivitas ibadah oleh komunitas gereja aliran kharismatik. Bentuk dan sifat musik gospel rohani ini cenderung menunjukkan ciri-ciri dan sifat musik musik pop. Berdasarkan analisis musikal dan kontekstual, nampak interelasi antara unsur-unsur yang menonjol, yaitu syair dan melodi lagu yang didukung rhythm musik yang memberikan stimulasi emosi atau perasaan dan suasana tertentu yang sesuai dengan konteks ibadah. Syair atau lirik lagu terbingkai melodi lagu yang melodius repetitif (berulang-ulang) dan sekuen. Rhythm musik dengan beat yang jelas menjadi dasar irama lagu yang 
kuat untuk menekankan keserempakan dan soliditas tempo lagu yang dinyanyian oleh jemaat. Keberadaan musik dalam ibadah memiliki fungsi antara lain (1) lirturgis, (2) komunikasi (3) pengajaran (dokrin), (4) pewartaan injil, dan (5) integrasi sosial jemaat (Bayu, Simatupang \& Ganap, 2014

Karakter musikal merupakan fenomena musikal yang terelasi dari sebuah permainan melodi, ritme, dan dinamika yang tergarap, terstruktur, dan terpola dengan kiat, model, dan gaya tertentu sehingga menghasilkan rasa tertentu pula (Ardana dalam Soedarsono \& Simatupang, 2014). Lagu-lagu yang memiliki karakter musikal pop (pop dalam hal musik yang poluler di masyarakat) mudah untuk disesuaikan dengan usia, misalnya remaja: musik-musik rock, soul, dangdut; anakanak: musik yang sesuai dengan karakter anak-anak seperti waltz; usia tua atau orang tua: musik yang slow, dan lagu-lagu tembang kenangan.

Seorang atau kelompok yang menggunakan musik akan disertai penghayatan dan penjiwaan yang mendalam. Melalui pengalamanpengalaman yang dilalui akan ditemukan nilai yang terkandung dalam musik tersebut, yakni seperti: nilai religius dengan menyanyikan lagu-lagu rohani, lagu himnal dapat menambah kekhusukan pada saat beribadah dan juga keyakinan agama akan lebih bertambah. Lagu yang bertemakan nasionalis memiliki nilai semangat juang dan kecintaan terhadap negara. Nilai bisnis/komersial dengan adanya musik dapat mendatangkan finansial/keuangan misalnya dari penjualan album rekaman, bisnis, pengadaan konser musik dengan menjual tiket, memproduksi dan memasarkan musik dengan cepat melalui media sosial seperti Youtube.

Tingkat nilai estetis ditentukan dari tingkat pengertian serta kemampuan persepsi seorang pendengar tentang tiga unsur utama musik, yaitu: melodi, ritme, dan harmoni sangat menentukan nilai keindahan musik atau suara yang didengarnya. Seorang yang paling awam tentang ilmu musik yang paling menentukan adalah unsur melodi. Bagi mereka yang agak baik pengertiannya, unsur irama akan memberi nilai tambah. Demikian pula apabila pengertian seseorang dilengkapi dengan ilmu harmoni maka ke 3 unsur tersebut pasti akan dapat memberi nilai tambah tentang keindahan yang kita dengar ${ }^{18}$.

Berdasarkan penjelasan di atas, tingkat penilaian estetis musik dapat diartikan bahwa semakin bertambah unsur atau komponen musik maka bertambah pula nilai estetis musik tersebut. Dalam setiap

\footnotetext{
${ }^{18}$ Sunarto, Estetika Musik: Autonomis versus Heteronomis dan Konteks Sejarah Musik (Promusika Junal Pengkajian, Penyajian, dan Penciptaan Musik, 2016)
} 
ide musikal dari seorang pencipta musik mempunyai makna dan fungsi yang bertujuan untuk menggambarkan, baik itu ide berdasarkan pengalaman berharga yang ingin diungkapkan lewat penggambaran musik ataupun sebagai respon akan fenomena yang terjadi dilingkungan pembuat musik. Bahkan ada juga yang sekedar mengolah kreativitas dalam produksi musik dengan tujuan finansial.

\section{KESIMPULAN}

Estetika musik memiliki manfaat
sebagai suatu pandangan yang bertujuan
mempersepsi sebuah karya musik dengan baik
sesuai nilai-nilai yang terkandung didalamnya.
Estetika hanya dapat dipahami di dalam
persoalannyamelalui sebuah media yaitu untuk
memahami keindahan bukan untuk mengalami
keindahan. Keindahan seni kreatif hasil karya
manusia sangat tergantung dari seluruh potensi
budaya, baik yang melibatkan kondisi mental,
spirit, lingkungan hidup, pengalaman-
pengalaman batin dan reaksi-reaksinya
Melalui sajian musik yang berunsur
digital dipersepsikan menjadi suatu aspek
estetika oleh kalangan generasi milenial.
Walaupun estetika musik tidak hanya
menyangkut soal rasa, akan tetapi juga masalah
intelegensi yang berorientasi pada kemajuan
suatu teknologi musik. Akan hal itu, generasi
milenial dikalangan gereja kharimatik
ekspresi ketika mendengar musik berunsur

digital tersebut. Musik dijadikan salah satuhal substansi ketika mengikuti peribadatan dan faktor penting dalam persekutuan untuk memuji dan memuliakan Tuhan.

Maka dari itu, musik pada generasi milenial juga terdapat di gereja yang dalam hal ini yaitu musik berteknologi digital. Perpaduan dari hasil komposisi elemen musikal lagu bertujuan untuk menghasilkan efek bunyi yang dinamis sehingga memiliki nilai estetis yang kaya warna suara dari bunyi-bunyi musik elektonis berbau digital seperti unsur synteziser, komposisi sequenser dan jenis instrumen drum pad. Bahkan dapat dikatakan bahwa estetika musik di gereja kharismatik seperti IFGF selalu mengikuti perkembangan estetika musik sekuler dalam dunia musik populer.

Bahwa kemudian estetika musik generasi milenial ditentukan pada pengetahuan dan pengalaman yang dimiliki oleh pendengar melalui kualitas telinga pada generasi milenial. Sehingga ditentukannya jenis musik berunsur teknologi digital di atas karena dominasi pilihan selera keindahan musik yang diminati oleh generasi milenial.

\section{DAFTAR PUSTAKA}

Ali, Hasanuddin \&Purwandi. 2016. The Urban Middle-Class Millennials. Jakarta : Alvara Research Center

Christ, William \& Richard, Delone. tanpa tahun, Introduction to Materials And Structure of Music, Prentice Hall, INC, Englewood Clifts, New Jerse 
Gie, Liang. 1983. Garis Besar Estetik (Filsafat Keindahan). Yogyakarta : Supersukses Hardjana, Suka 2018. Estetika Musik. Yogyakarta : Art Music Today Institute, Research IDN. 2019. Indonesia Millennial Report 2019. IDN Media

Kusumawardhana, Saptaputra dan Ramdan. 2019. Towards millennial's music genre: psychology of music in a restaurant. dalam Research Gate :

Lawrenz, Jürgen., Music and the Aesthetic Copernican Revolution of the Eighteenth Century, The European Legacy, Vol 25 No 2, Okt 2019 pp 186-202.

Nafis, Minawati \& Ediwar, Estetika Musik Zapin Sebagai Budaya Populer di Pekanbaru dalam, Bercabik : Jurnal Penciptaan dan Pengkajian Seni Pascasarjana ISI Padang Panjang Vol.2 No.2 Oktober 2014

Saputra, Albert Aristikhus. 2017. Aplikasi Teknologi Musik Digital dalam Kebaktian di Gereja International Full Gospel Fellowship (IFGF). Yogyakarta : Universitas Gadjah Mada

Stein, Leon. 1979. Structure and Style. USA: Warner Bros, Publications

Soedarso, R.M \& Simatupang G.R. Lono L.,Karaker Musikal Lagu Gede Kepesindenan Kawawitan Sunda. dalam Resital Jurnal Seni Pertunjukan Vol. 15 No. 1, Juni 2014 pp. 18-31
Supriyadi.. Nilai Estetis Musik dalam Rentang Sejarah Musik Baratdalam Tonika Vol. 2 No. 1 Mei 2019 pp.118

Sunarto.,Estetika Musik: Autonomis versus Heteronomis dan Konteks Sejarah Musik dalam Promusika : Junal Pengkajian, Penyajian, dan Penciptaan Musik Vol 4, No. 2, Oktober 2016, pp. 102-116

Wijiyanto, Bayu, Simatupang, Lono \& Ganap, Victorius. Musik Gospel Sebagai

Ekspresi Spritual Kristen Kharismatik dalam Journal of Urban Society's Arts Vol13. No 2, 2014 pp. 84-98

\section{Webtografi}

Haryanto, Alexander (19 November 2016) Memahami Selera Musik Milenial, Tirto https://tirto.id/memahami$\underline{\text { selera-musik-milenial-b49a }}$

Ardina, Ika (04 Maret 2108). Rentang usia generasi milenial diperbarui. Beritagarhttps://beritagar.id/artikel/g aya-hidup/rentang-usia-generasimilenial-diperbarui

Ramadhan, Maulana (21 November 2017)Memahami Selera Musik Generasi Milenial. Kumparan

https://kumparan.com/@kumparanstyle/me mahami-selera-musik-generasi-milenial 